\title{
SOME ASPECTS ON VARIETIES OF ENGLISH PRONUNCIATION
}

\author{
Fotima Bakhromovna Akhrarova
}

Phd, Senior Lecturer, National University Of Uzbekistan

\section{ABSTRACT}

The American variant of English has been very thoroughly described by many prominent scholars both in this country and in the USA. In this book, however, we shall try to follow the conception introduced by A.D. Shweitzer in his sociolinguistic approach to the treatment of contemporary speech situation in America.

KEYWORDS: - Vocabulary, listening, pronunsiation, speaking, reading, writing, pedagogical technologies, interactive, intellectual, foreign language.

\section{INTRODUCTION}

The sociolinguistic situation in the United States is very complicated. It is molded by certain linguistic, cultural, historic, demographic, geographic, political and other factors. Generally speaking, the situation in the USA may be characterized as exoglossic, i.e. having several languages on the same territory, the balance being in favor of American English. It is true, of course, that the formation of the American Standard underwent the influence of minorities' languages, but its starting point was the English language of the early 17th century. However, time has passed, American English has drifted considerably from English though as yet not enough to give us ground to speak of two different languages. Thus we speak of the national variant of English in America. American English shows a lesser degree of dialect than British English due to some historical factors: the existence of Standard English when first English settlers came to America, the high mobility of population, internal migrations of different communities and so on. As regards pronunciation, however, it is not at all homogeneous. There are certain varieties of educated American speech. In the USA three main types of cultivated speech are recognized: the Eastern type, the Southern type and Western or General American.

1. The Eastern type is spoken in New England, and in New York city. It bears a remarkable resemblance to Southern English, though there are, of course, some slight differences.

2. The Southern type is used in the South and SouthEast of the USA. It possesses a striking distinctive feature - vowel drawl, which is a specific way of pronouncing vowels, consisting in the diphthongization and even diphthongization of some pure vowels and monophthongization of some diphthongs at the expense of prolonging («drawling») their nuclei and dropping the glides.

3. The third type of educated American speech is General American (GA), also known as Northern American or Western American spoken in the 
CURRENT RESEARCH JOURNAL OF PHILOLOGICAL SCIENCES 2(9): 73-75,

September 2021

DOI: https://doi.org/10.37547/philological-crjps-02-09-15

ISSN 2767-3758

(C)2021 Master Journals

Crossref doi

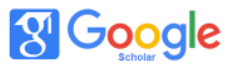

Accepted25 $5^{\text {th }}$ September, 2021 \& Published $30^{\text {th }}$ September, 2021

central Atlantic States: New York, New Jersey, Wisconsin and others. GA pronunciation is known to be the pronunciation standard of the USA. There are some reasons for it. GA is the form of speech used by the radio and television. It is mostly used in scientific, cultural and business intercourse. Also in two important business centers GA is the prevailing forms of speech and pronunciation, though New York is situated within the territory where Eastern American is spoken, and St. Louis is within the region of Southern American. In this chapter we shall give an outline of GA accent. We will then point to differences between this accent and RP.

1. There is no strict division of vowels into long and short in GA, though some American phoneticians suggest that certain GA vowels are tense and likely to be accompanied by relative length: [i:] in seat, [u:] in pool. They also admit that a slight rise in tongue position during the pronunciation of tense vowels leads to a diphthongal quality of tense vowels which contrasts to a monophthongal quality of lax vowels.

2. Classification of vowels according to the stability of articulation is the most controversial subject in GA. Some diphthongs are treated in GA as biphonemic combinations. The inventory of GA diphthongs varies from three to twelve phonemes. Following DA. Shakhbagova we distinguish here five diphthongs in GA: [ei], [ai], foi], [auj, [ou].

3. Another very important feature that causes different interpretations of diphthongs and vowel length in GA is the pronunciation of [r] sound between a vowel and a consonant or between a vowel and. a silence: turn [t3: rn], bird [b3: rd], star [star]. It has been estimated that $2 / 3$ of American population pronounce [r] and $1 / 3$ omit it. Thus GA is rhotic in words like far, core, etc. (when [r] follows the vowels and ends the word), this sound is consonantal and non-syllabic according to $\mathrm{Ch}$. Thomas. It involves the characteristic hindering of the free flow of breath which we associate with consonants. The sound [r] in far closes the syllable more definitely than in British Received Pronunciation of the word [fa]. On the other hand, there is a vocalic, or vowel-like and syllabic [r], that occurs in words like bird, murmur (after a vowel and before a consonant). Ch. Thomas writes that in such cases we should better transcribe the words bird and murmur like [brad] and [murmur]. In such cases $[\mathrm{r}]$ is responsible for the characteristic vowellike quality within the syllable; it is responsible for syllabic quality as well. That's why Ch. Thomas says that $[\mathrm{r}$ ] syllabic in bird and [r] non-syllabic in far should be transcribed differently. According to V.A. Vassilyev it is still the vowel of the word that forms a syllable ([3;] in bird, [0:] in corn, etc.), not the syllabic [r] sound. He mentioned although that all the vowel sounds in pre - $[\mathrm{r}]$ position sound more like [a], [r] gives the preceding vowel a retroflex coloring. It means that the tip of the tongue glides to the retroflex position without, however, staying there long enough to produce a full-fledged retroflex [r] sound, [r] also prolongs the vowel a little. V.A. Vassilyev uses the term «[r] compensating» vowels for the vowels in such words in British Received Pronunciation.

4. One more peculiar feature of pronunciation of vowels in American English is their nasalization, when they are preceded or followed by a nasal consonant (e.g. in such words as take, small, name, etc.). Nasalization is often called an American twang. It is certain that we have not covered here all the cases of different intonation structures used in RP and G.A. Recently there have appeared in this country several papers and books on the subject, so for further information see those books.

Concludingly we can say, the consideration of personal names and naming as fundamental aspects of social processes that have critical bearing on anthropological understanding of personhood, kinship, and gender. We tried to examine, naming practices may express information about a broad range of social classification. European names, 
CURRENT RESEARCH JOURNAL OF PHILOLOGICAL SCIENCES 2(9): 73-75,

September 2021

DOI: https://doi.org/10.37547/philological-crjps-02-09-15

ISSN 2767-3758

(C)2021 Master Journals

crossref do) 801 Google

Accepted25th September, 2021 \& Published 30 ${ }^{\text {th }}$ September, 2021

among others, can provide information about gender, kinship, class, marriage, ethnicity, and religion, reflecting existing classificatory groups. In many societies, changes in social status are reflected by name changes and in some, the name change effects the shift in status.

\section{REFERENCES}

1. Tikhonov R.M. some Some features of the prosodic organization of reading monologic text and spontaneous monologue-story // Phono style problems.- M., 1980.

2. Torsuev G.P. Questions accentology of modern English. - M. L., 1960.

3. Torsuev G.P. Problems of theoretical phonetics and phonology. - M., 1969.

4. Ismatullayeva, N. R. (2020). Probability Prediction Strategy In Simultaneous Interpretation. CURRENT RESEARCH JOURNAL OF PHILOLOGICAL SCIENCES, 1(01), 1-6.

5. Parhadjanovna, S. S. (2020). English and uzbek meat idioms reflected by culture and history. ACADEMICIA: An International Multidisciplinary Research Journal, 10(5), 832836. 